\title{
S9 - Susceptibilidad de cerdos criados artesanalmente a infeccio- nes por norovirus humanos en zonas rurales de Nicaragua
}

\author{
Fredman González \\ Maestría en Microbiología Médica, Universidad Nacional Autónoma de Nicaragua, León, Nicaragua
}

*Autor al que se dirige la correspondencia: fili.bucardo@hotmail.com

\section{Resumen}

Torovirus es la mayor causa de gastroenteritis viral en el mundo, genética y antigénicamente las cepas huma1 nas y porcinas se relacionan. La información se limita en zonas rurales donde los cerdos domésticos están expuestos a heces humana que facilitan la transmisión. La presencia de antígenos de grupos histo-sanguíneos (HBGAs) se conocen como factores de susceptibilidad para NoV en seres humanos y para modelo de lechones libre de gérmenes, pero su papel en la susceptibilidad en ambientes domésticos es desconocido. La investigación estableció la seroprevalencia en cerdos domésticos de tres cepas de norovirus humano en formato VLP (partículas virales sintéticas); y la distribución de HBGAs en relación con los títulos de anticuerpos IgG y la caracterización adicional de la cepa GII.4-VLP de NoV por bloqueo de unión a mucinas gástricas de cerdo (PGM). La mayoría de cerdos fueron seropositivos a los tres VLPs (58-70\%). La seropositividad y la reactividad cruzada aumentó significativamente con la edad; los sueros de cerdos no bloquearon la unión del NoV GII.4 VLP (Dijon) a PGM lo que sugiere que no hay infección previa con este genotipo. La mayoría de cerdos fueron H-positivo (84\%), un factor de susceptibilidad para infecciones humanas, pero los títulos de anticuerpos de IgG fueron mayores en $\mathrm{H}$-negativo $(\mathrm{GMT}=247)$ que en cerdos H-positivo $(\mathrm{GMT}=57)$, esta diferencia en los títulos de anticuerpos sólo se observó en cerdos $\leq 1$ mes. Los datos serológicos demuestran que la población porcina está expuesta a infecciones por NoV, y la asociación de HBGAs requiere otros estudios.

Palabras claves: IgG, norovirus porcino, Nicaragua, zoonosis, HBFA, mucina gastrica de cerdo

\begin{abstract}
I nformation about porcine norovirus (PoNoV), genetically similar to human NoV (HuNoV), is limited from rural areas where household-raised pigs are heavily exposed to fecal material which could facilitate transmission. Histo blood group antigens (HBGAs) are known susceptibility factors to NoV in humans and in a germfree piglet model but their role in susceptibility in the porcine population is unknown. This study reports the seroprevalence and antibody titers to human norovirus (NoV) VLPs in household raised pigs; and, the distribution of HBGAs in relation to NoV IgG antibody titers and further characterization by blocking of GII.4 VLP binding to pig gastric mucins (PGM). The majority of pigs were seropositive to all three VLPs tested (58-70\%) with seropositivity and cross-reactivity increasing significantly with age. However, pig sera could not block the binding of NoV GII.4 VLPs (Dijon) to PGM suggesting no previous infection with this genotype. The majority of the pigs were H-positive (84\%), a susceptibility factor for human infections. IgG antibody titers were however higher in H-negative (GMT $=247)$ as compared with H-positive $(\mathrm{GMT}=57)$ pigs, this difference in antibody titers was only observed in pigs $\leq 1$ month. Serological data show that the porcine population of Nicaragua is highly exposed to NoV infections, and the association to HBGAs warrants further investigation
\end{abstract}

Keywords: IgG; porcine norovirus; Nicaragua; zoonosis; HBGA; pig gastric muci 